\title{
KURIKULUM ZA PREDMET INFORMACIJSKA PISMENOST
}

\section{dr. sc. Beba E. Rašidović}

Univerzitet u Sarajevu, Fakultet za kriminalistiku, kriminologiju i sigurnosne studije, Sarajevo, Bosna i Hercegovina University of Sarajevo, Faculty of Criminal Justice, Criminology and Security Studies, Sarajevo, Bosnia and Herzegovina brasidovic@fkn.unsa.ba

\begin{abstract}
Sažetak
Kontekst informacijskog društva i društva znanja predstavlja izazov za nove politike obrazovanja, koje se prilagođavaju potrebama tržišta rada, a tržište rada zahtijeva stalno usavršavanje i stjecanje novih znanja i vještina, što podrazumijeva kontinuirani proces učenja. Metakompetencije informacijske pismenosti doprinose razvijanju kreativnih sposobnosti za cjeloživotno učenje kroz educiranje svih učesnika obrazovnih procesa o boljem, učinkovitijem, svrhovitijem i kvalitetnijem korištenju, za izgradnju znanja, relevantnih informacija i izvora informacija, bez obzira da li su informacijski izvori i informacije sadržane u njima analognog, digitalnog ili virtuelnog porijekla. Iz takvoga značaja informacijske pismenosti proizlazi potreba inkorporacije ovih metakompetencija, kao temeljnih, u sve nastavno-znanstvene procese. U kontekstu promjena u društvu, reformi unutar visokog obrazovanja, promijenjene obrazovne paradigme i načina učenja, a u skladu s daljim razvojem informacijske pismenosti, nameće se kao neophodna potreba definiranja kurikuluma informacijske pismenosti u skladu s načelima aktivnog učenja. Cilj ovoga rada je predstaviti okvirni kurikulum za nastavni predmet informacijska pismenost.
\end{abstract}

Ključne riječi: informacijska pismenost, metakompetencije informacijske pismenosti, samostalni nastavni predmet, kurikulum informacijske pismenosti

\section{Uvod}

Sve do druge polovine 20. stoljeća kurikulum i nastavni plan i program bili su sinonimi, a u današnjoj pedagoškoj znanosti postoje različita tumačenja kurikuluma, te se razvila i pedagogija kurikuluma kao subdisciplina i interdisciplinarno područje obrazovanja. Johnson (prema Pastuović 1999, 519) definira kurikulum kao "strukturirani niz željenih ishoda učenja određenih ciljevima učenja", a Knoll (prema Pastuović 1999, 519) kaže: "Povijesni koncept kurikuluma što ga je moderna odgojno-obrazovna znanost prihvatila odnosi se na proces učenja: koja znanja, sposobnosti, vještine, stavove i obrasce ponašanja treba učenik steći? S kojim sadržajima on treba biti suočen? Šta treba učiti? Kako i gdje treba učiti? Kojim koracima u učenju, kako, uz pomoć kojih nastavnih sredstava i pomagala učiti? Kako je utvrđeno postignuće ciljeva? Čitavo je ovo krajnje složeno područje pitanja obuhvaćeno nazivom kurikulum. U biti, kurikulum znači organizirani angažman procesa učenja i sadržaja s obzirom na određene svrhe i ciljeve. Oni mogu biti definirani kao ponašanje ili kao vrsta i stupanj određenih vještina, sposobnosti ili znanja." U razvijenim zemljama osnovna polazišta visokog obrazovanja temelje se na nacionalnom kurikulumu čije je ključno obilježje kompetencijski pristup visokom obrazovanju, a planiranje visokoškolskog kurikuluma odvija se na tri nivoa: državnom, fakultetskom i predmetnom. Ovakav pristup obrazovanju širi je od pristupa koji fakultet shvaća kao mjesto usvajanja znanja i prenošenja činjenica te, suprotno tome, kurikulum naglašava da je fakultet mjesto cjelovitog osobnog i socijalnog razvoja studenta u smislu stalnih promjena koje uvažavaju trajne vrijednosti nadograđujući na njih nova postignuća u svim znanostima, pružajući pritom svakome mogućnosti da vlastitim koracima dostigne željene ciljeve, zadaće i putove razvoja (Previšić 2007). Koncept kurikuluma sastavljen je od četiri elementa: ciljeva učenja, sadržaja koje treba naučiti kako bi se postigli ti ciljevi, organizacije i metoda poučavanja i ishoda učenja (Pastuović 2012, 278). Kurikularni pristup obrazovanju počiva na aktivnostima osobe koja uči u smislu osobne odgovornosti za učenje i samousmjeravanje i na ishodima učenja koji očituju šta su studenti naučili i šta od svojih znanja mogu pokazati i primijeniti. U literaturi postoji mnoštvo 
sličnih definicija ishoda učenja, a najčešća je da su to iskazi o tome šta se od studenata očekuje da znaju, razumiju, mogu napraviti i vrednovati kao rezultat procesa učenja (Jenkins i Unwin, prema Kennedy 2006, 20), za razliku od obrazovnih ciljeva ili ciljeva učenja, koji se odnose na namjere predavača i opisuju ono što nastavnik čini da bi studenti znali, razumjeli i mogli izvršiti na kraju određenog razdoblja učenja (Lončar-Vicković i Dolaček-Alduk 2010, 145). Adam (prema Kennedy 2006, 21) određuje ishode učenja kao "napisane iskaze o onome šta se očekuje da su studenti u stanju uraditi na kraju određenog modula/kursa ili kvalifikacije", a Allan (prema Machala 2009, 43) kaže da "ishodi opisuju što student zaista postiže, naspram onog što institucija namjerava poučavati", pa je u svim definicijama ishoda učenja naglasak na studentskim postignućima, a ne na sadržaju učenja, te na onome šta su studenti u stanju pokazati po okončanju aktivnosti učenja. Gosling i Moon (prema Machala 2009, 49) međutim smatraju da ne postoji potpuno ispravno pisanje ishoda učenja.

Utvrđivanje kompetencija studenata polazna je tačka planiranja kurikuluma zasnovanog na ishodima učenja, a kompetencije predstavljaju kombinaciju znanja, sposobnosti, vještina i stavova te obuhvataju kognitivne (znanje - eksplicitno i tacitno), funkcionalne (know-how), personalne (ponašanje) i etičke kompetencije (osobne / društvene vrijednosti). Prema Tuning pojmovniku (Uvod u projekt Usklađivanja obrazovnih struktura u Europi 2007, 93) kompetencije predstavljaju dinamičku kombinaciju kognitivnih i metakognitivnih vještina, znanja i razumijevanja, međuljudskih i praktičnih vještina te etičkih vrijednosti. U visokom obrazovanju kompetencije se razvijaju u svim programskim jedinicama i utvrđuju se posebno za svaki nivo studijskog programa. Kako kompetencije u sebi udružuju znanja i njihovu primjenu, mogu se podijeliti na opće / generičke i stručne kompetencije, pri čemu opće čine: instrumentalne, interpersonalne i sistemske kompetencije (Lončar-Vicković i Dolaček-Alduk 2010, 24-25). Instrumentalne obuhvataju kognitivne, metodološke, tehničke i lingvističke sposobnosti, interpersonalne individualne sposobnosti kakve su socijalne vještine (socijalna interakcija i saradnja), a sistemske - sposobnosti i vještine važne za sistemski pristup i kombinacija su razumijevanja, senzibilnosti i znanja. Upotreba ovih kompetencija podrazumijeva prethodno stjecanje instrumentalnih $\mathrm{i}$ interpersonalnih kompetencija.

Najvažnije opće kompetencije su sposobnost analize i sinteze, sposobnost učenja, rješavanja problema i primjene znanja, sposobnost prilagođavanja, briga za kvalitetu, vještine upravljanja informacijama te sposobnost za samostalan i timski rad. Stručne su kompetencije uže i povezane su s određenim aka- demskim područjem. Pomoću ishoda učenja, student demonstrira svoja znanja, sposobnosti i vještine i stječe određene kompetencije.

\section{Informacijska pismenost}

Informacijska pismenost se najčešće smješta u područje općih ili generičkih kompetencija, ali su u bibliotečko-informacijskoj znanosti sve češći prijepori o tome je li informacijska pismenost dio općeg obrazovanja s vještinama lako prenosivim na bilo koje područje, ili su informacijska pismenost i učenje unutar discipline "intrinzični" (Thompson i Lathey 2013,2) partneri u učenju zasnovanom na ispitivanju $\mathrm{i}$ istraživanju. Christine Bruce smatra da je "učenje odnos između onoga koji uči i onoga što uči, a pri tome fokus nije na studentu, ni na nastavniku, a ni na informacijama, nego na odnosu između ovih elemenata" (Thompson i Lathey 2013, 2). Zato Thompson i Lathey ističu da informacijska pismenost nije nešto što se može naučiti za jedan ili dva školska časa, nego zahtijeva učenje koje se razvija uz praksu tokom godina kako bi se usavršile metode ispitivanja i traganja koje odgovaraju najvišim oblicima akademskog istraživanja. U odnosu na dvije povezane vrste znanja, znanja iz discipline ili predmetnog znanja i sistemskog ili strateškog znanja, informacijska pismenost je vrsta strateškog znanja koje uključuje učenje zasnovano na istraživanju, rješavanju problema i kritičkom mišljenju, te cilj informacijske pismenosti nije samo poučavanje studenata uspješnom prikupljanju informacija nego poučavanje studenata da uspješna potraga za informacijama jednako zavisi i od njihovog prethodnog znanja i produbljivanja znanja o predmetu, te tako informacijska pismenost $i$ znanstveno područje imaju sinergijski odnos s naglaskom na kognitivni razvoj i transformaciju (Thompson i Lathey 2013, 6).

Kako je informacijsko okruženje dinamično i kolaborativno, koncept informacijske pismenosti predstavlja sveobuhvatni okvir za djelotvorno sudjelovanje u društvenim medijima i online zajednicama, te prerasta u svojevrsnu metapismenost kako je vide Mackey i Jacobson $(2011,62)$, koja objedinjuje različite modalitete pismenosti povezane $\mathrm{s}$ rastom $\mathrm{i}$ razvojem tehnologije.

$\mathrm{Na}$ tom se fonu osmislio okvirni kurikulum za informacijsku pismenost $u$ visokoškolskom okruženju kao vrstu otvorenog fleksibilnog kurikuluma $s$ okvirnim uputama i mogućnošću prilagođavanja i nadopunjavanja. Marsh (prema Kovačević i Lovrinčević 2014, 61) smatra da su ključna obilježja sveobuhvatnog i dobro osmišljenog okvirnog kurikuluma snažne veze između teorije i prakse, spoznaje o metodici, učenju i resursima, te svijest nastavnika o mogućnostima koje kurikularni pristup pruža u 
produkciji i distribuciji znanja. Okvirni kurikulum stoga obično sadrži:

- temeljna načela ili platformu

- opseg i parametre kurikulumskog područja

- općenite ciljeve i svrhe predmeta u kurikulumskom području

- smjernice za izradu nastavnog programa predmeta

- sadržaj

- nastavna načela i načela učenja

- smjernice za vrednovanje predmeta

- kriterije za akreditiranje i ovjeravanje predmeta

- buduće pomake u tom području (Kovačević i Lovrinčević 2014, 62)

Kako su društvene i tehnološke promjene presudne za uvođenje novih metoda i tehnika u obrazovanje i unapređenje obrazovnog procesa kroz izgradnju interdisciplinarnih kurikulumskih pristupa, tako se učinkovito poučavanje informacijske pismenosti može ostvariti prožimanjem informacijske pismenosti i sadržaja u okviru nastavnih planova i programa kako bi se dosegao krajnji cilj informacijske pismenosti utemeljen u sintagmi "učiti kako učiti". U okvirnom kurikulumu informacijske pismenosti nastojao se postići takav cilj. Kurikulum je zasnovan na Modelu prožimanja komponenti (Rašidović 2011; 2016), koji se odnosi u isto vrijeme i na koncepte i na izvore $\mathrm{i}$ alate, te nastoji povezati opće kompetencije $\mathrm{i}$ vještine prenosive $\mathrm{i}$ primjenjive $\mathrm{u}$ bilo kojem području s kontekstualnim kompetencijama i znanjima iz fakultetskog kurikuluma u smislu u kojem Lloyd definira tri široka pejzaža informacijske pismenosti: obrazovni, pejzaž radnog mjesta i pejzaž zajednice (prema Špiranec i Kos 2013, 3). Informacijska pismenost kao metapismenost uma- njuje teorijske razlike i jača veze među različitim vrstama pismenosti novog doba i podupire ciljeve cjeloživotnog učenja te tako kroz ishode učenja i poučavanja pomaže stjecanju metakompetencija što proizlaze iz sva tri pejzaža kao svojevrsnih društveno-kulturnih praksi povezanih s informacijama i znanjem. Iako su nastali u visokoškolskom okruženju, Model prožimanja komponenti, kao i kurikulum, moguće je prilagoditi svakom obrazovnom okruženju odabirom onih segmenata za koje se utvrdi da o njima postoje praznine u znanju koje treba popuniti.

\section{Kurikulum za predmet Informacijska pismenost}

Naziv predmeta: Informacijska pismenost

Cilj i svrha predmeta: Osposobljavanje studenata za samostalno učenje i izgradnju znanja u interakciji s mnoštvom široko distribuiranih izvora informacija, te etičko sudjelovanje u zajednicama učenja i obrazovanja i učešće u civilnom društvu.

Ishodi učenja: Očekuje se da će studenti na kraju programa steći kompetencije samostalnog pristupa i pretraživanja izvora informacija analognog, digitalnog i virtuelnog porijekla u bilo kojem obliku i formatu, pronalaženja, procesiranja, vrednovanja, izlučivanja i upravljanja relevantnim informacijama, njihove analize, kritičkog promišljanja, sinteze, organizacije, interpretacije i predstavljanja u cilju odgovornog stvaranja vlastitog informacijskog proizvoda kroz pripremanje ispita, pisanje eseja, prezentacija, seminarskih i završnih radova u svrhu usvajanja znanja i osobnog razvoja u skladu s konstruktivističkim pristupom učenju i izgradnji znanja, te učešća u civilnom društvu. 


\begin{tabular}{|c|c|c|c|c|c|c|}
\hline 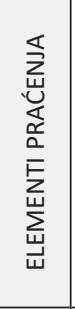 & 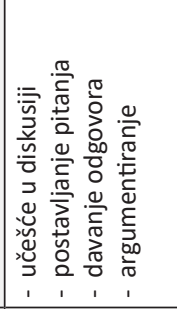 & 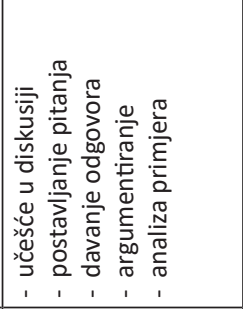 & 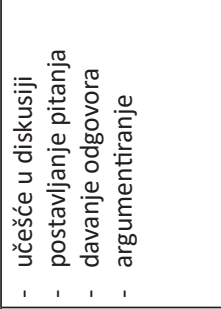 & 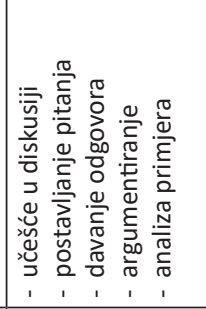 & 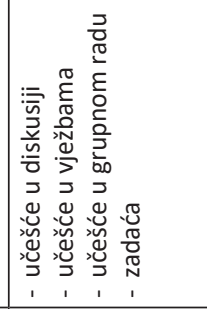 & 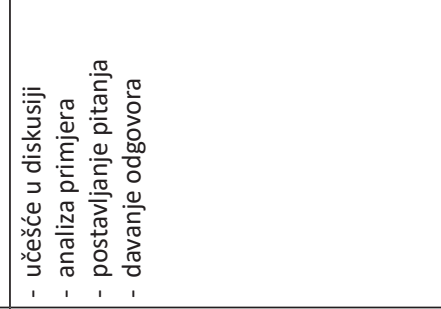 \\
\hline 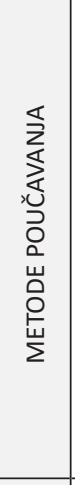 & 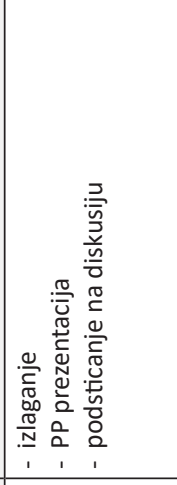 & 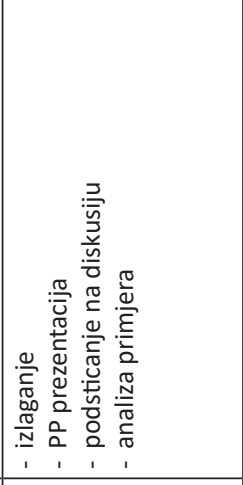 & 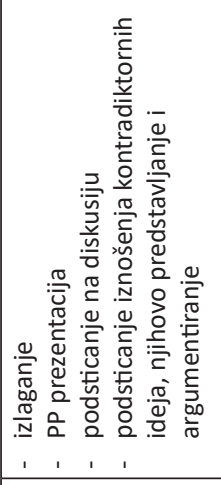 & 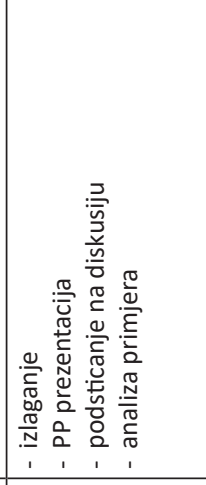 & 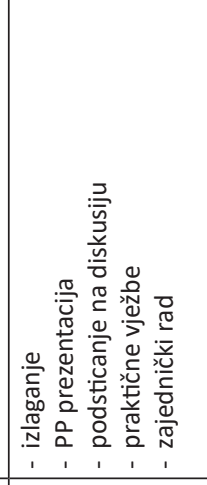 & 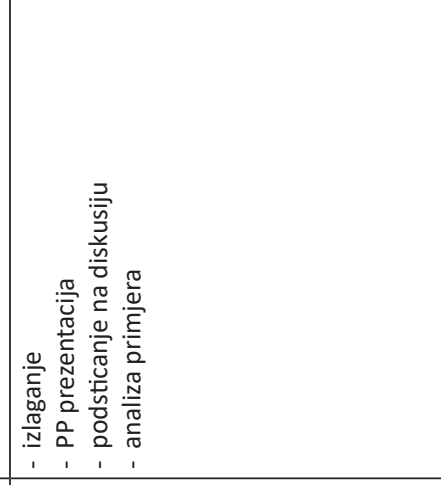 \\
\hline 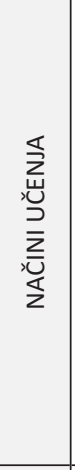 & 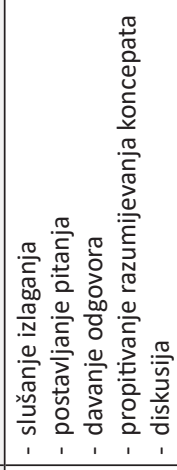 & 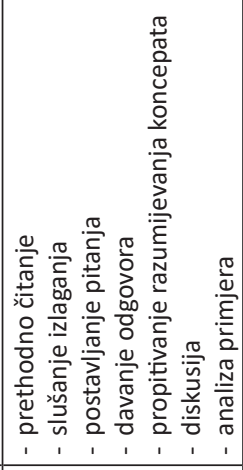 & 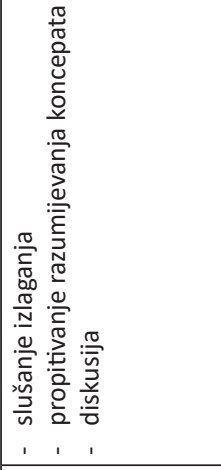 & 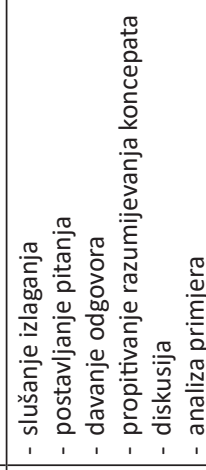 & 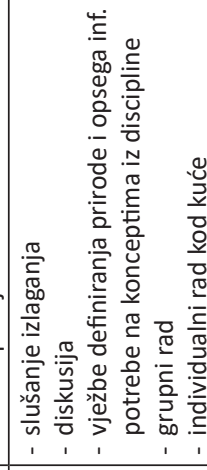 & 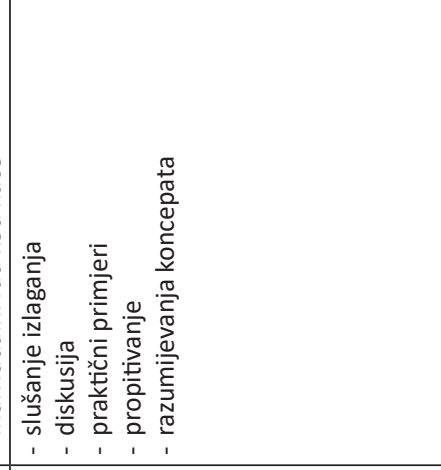 \\
\hline 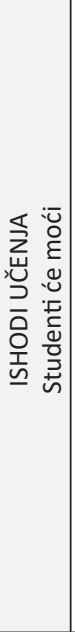 & 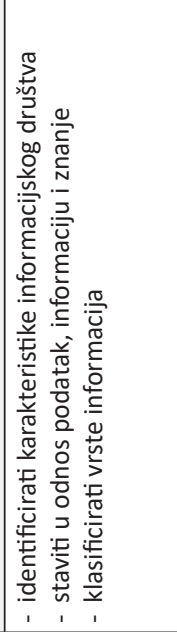 & 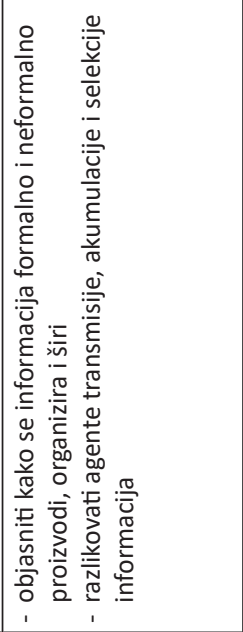 & 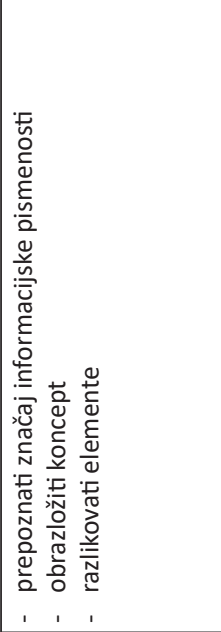 & 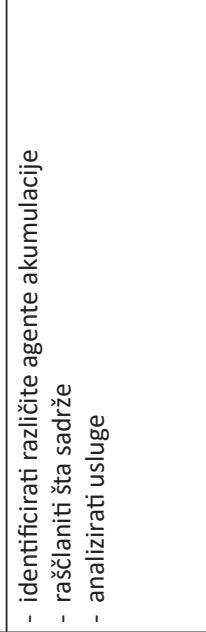 & 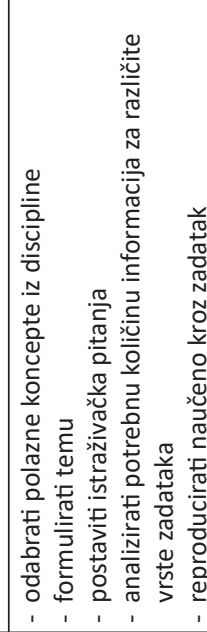 & 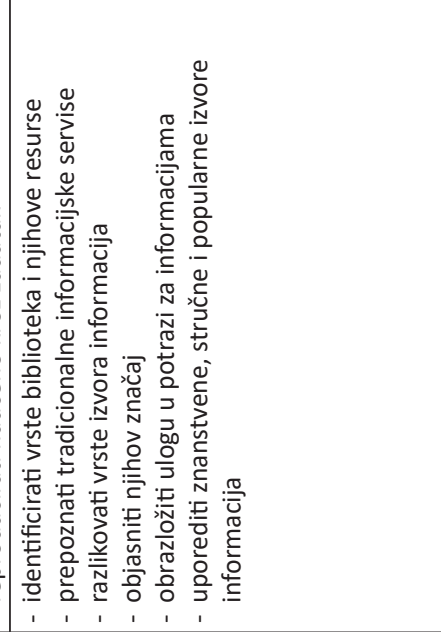 \\
\hline 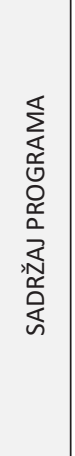 & 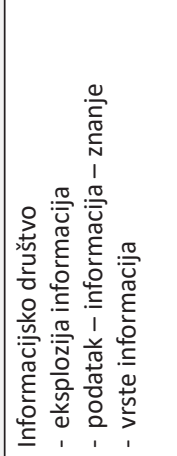 & 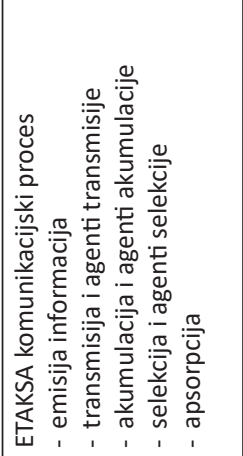 & 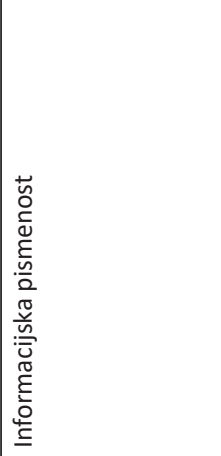 & 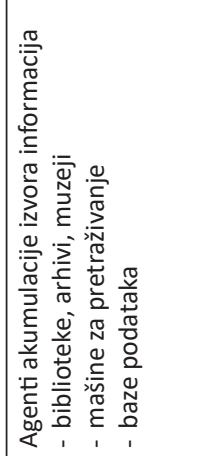 & 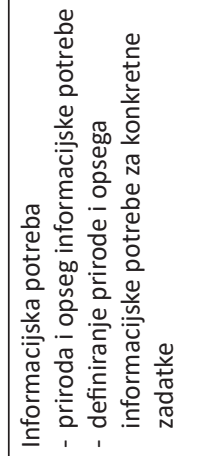 & 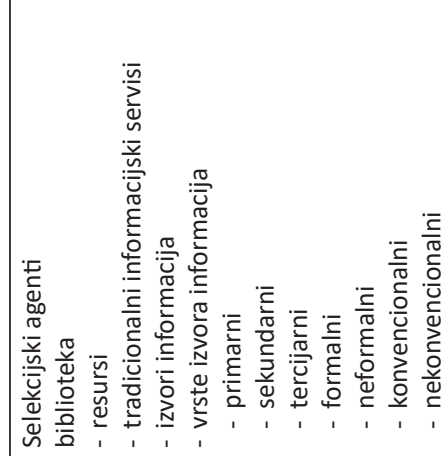 \\
\hline
\end{tabular}




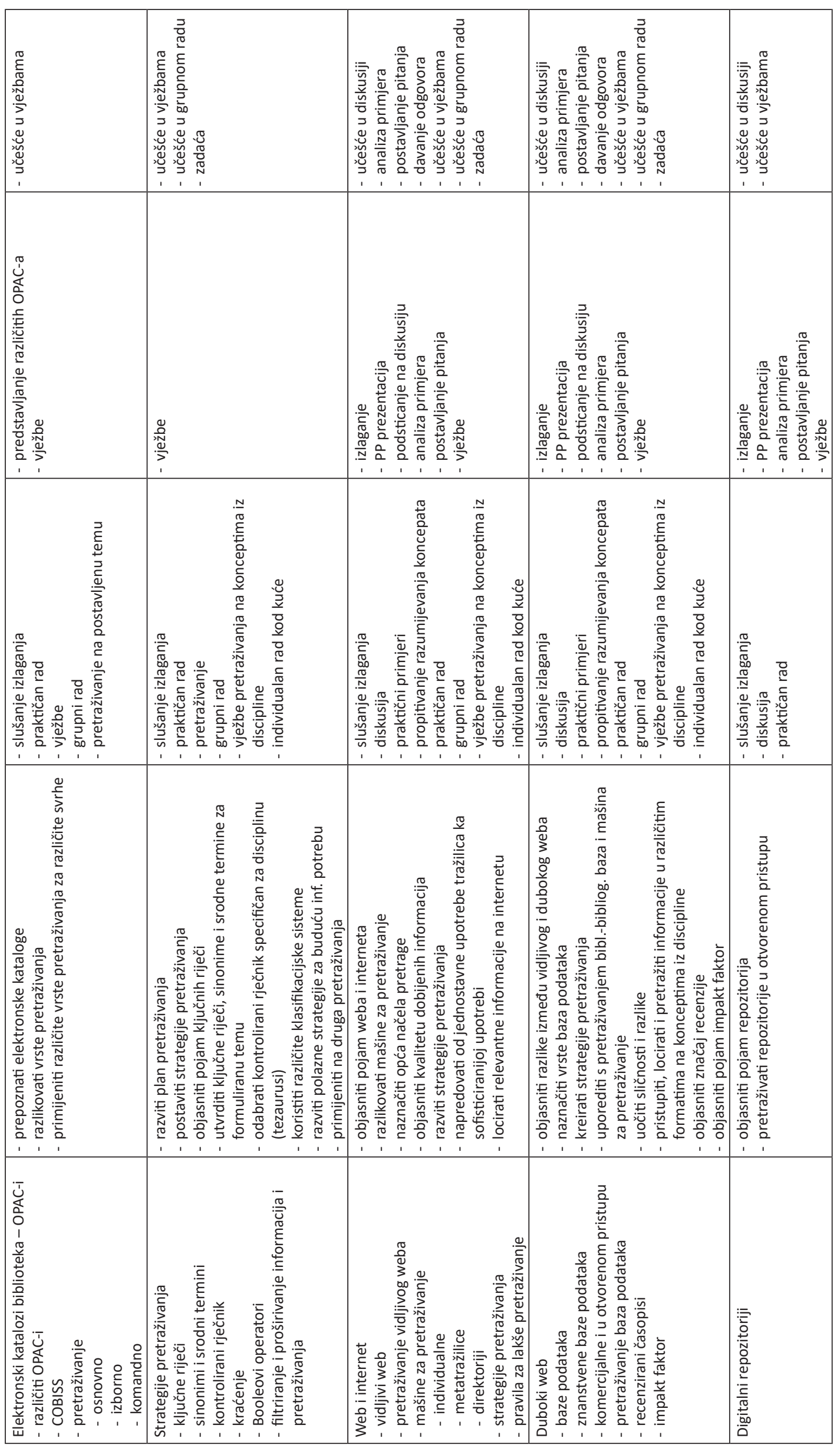




\begin{tabular}{|c|c|c|c|c|c|}
\hline 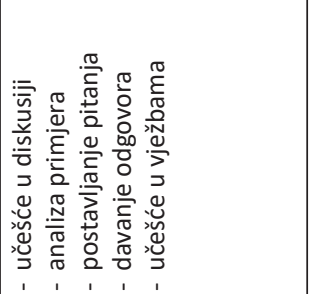 & 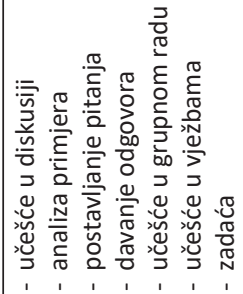 & & 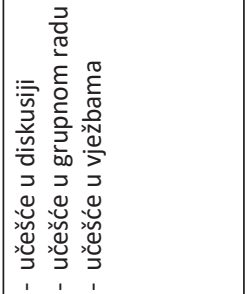 & 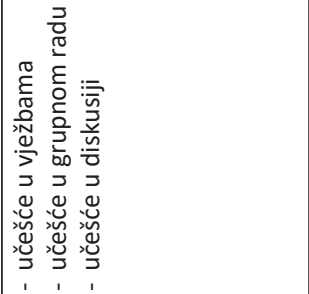 & 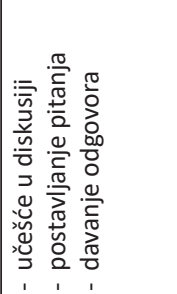 \\
\hline 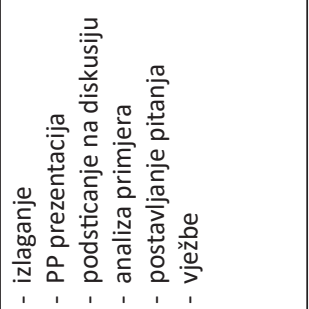 & 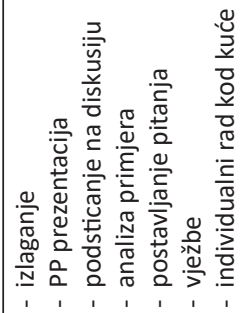 & & 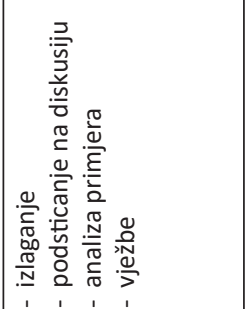 & 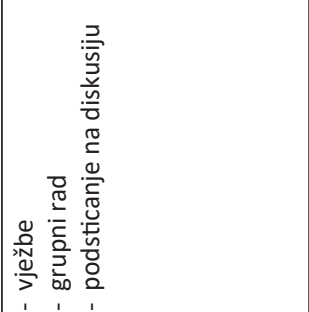 & 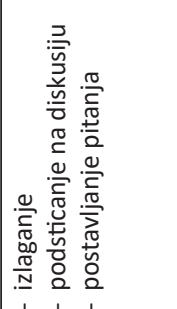 \\
\hline 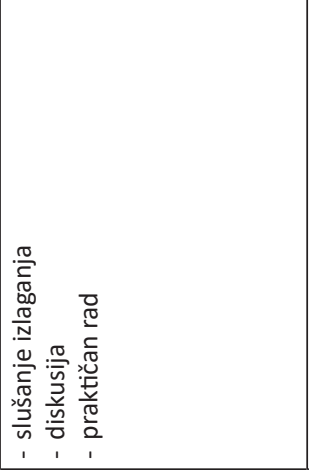 & 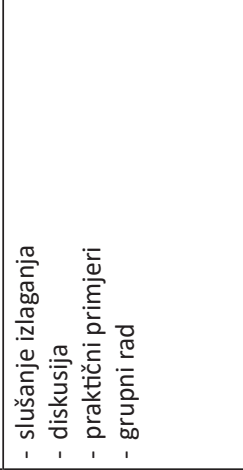 & & 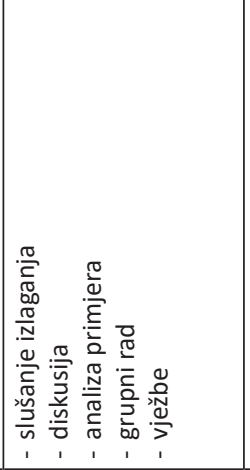 & 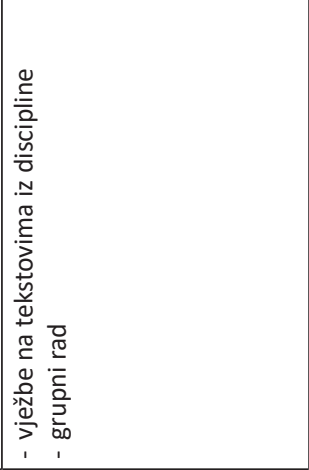 & 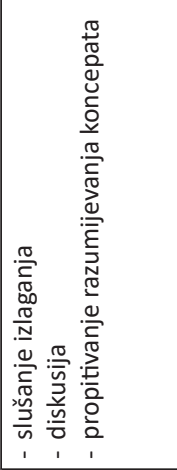 \\
\hline 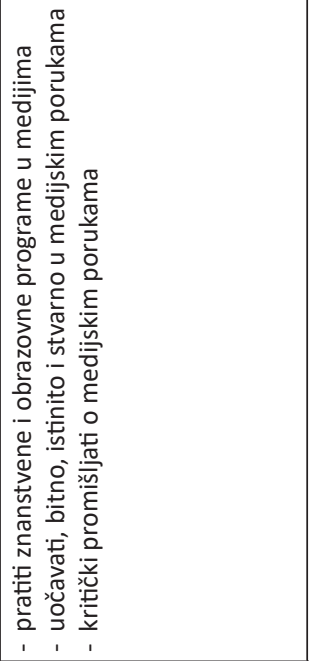 & 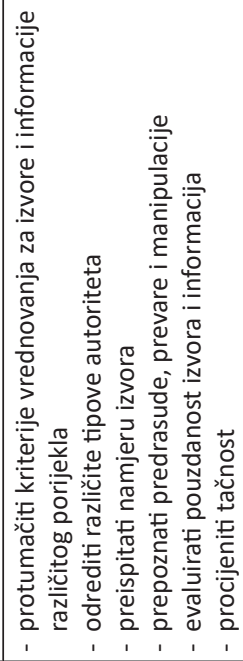 & 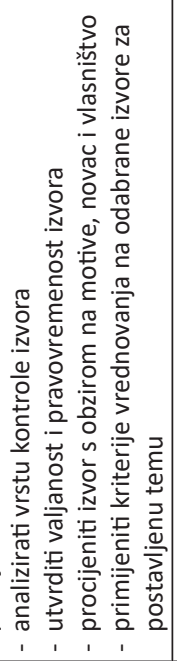 & 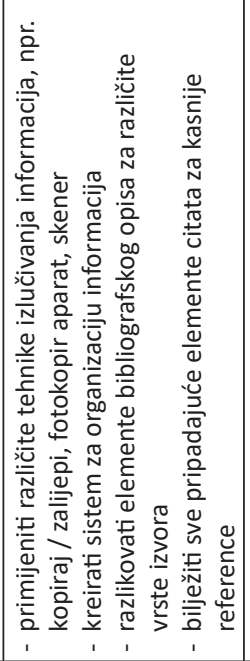 & 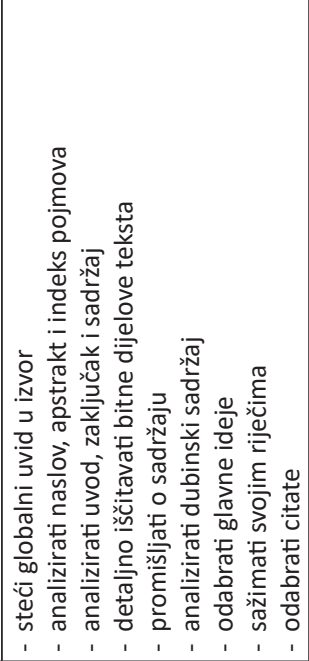 & 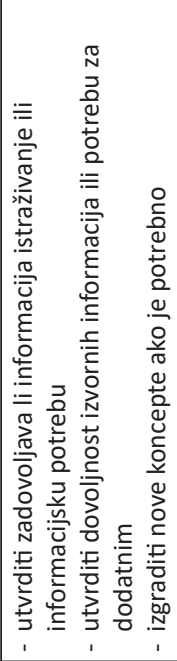 \\
\hline 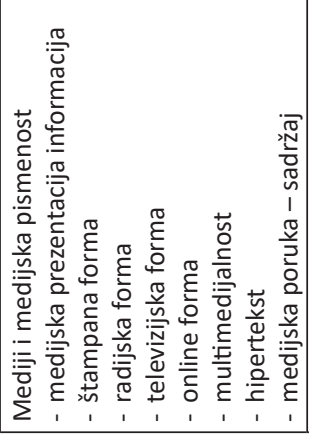 & 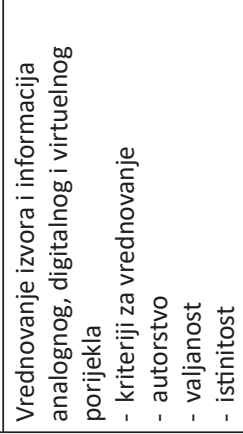 & 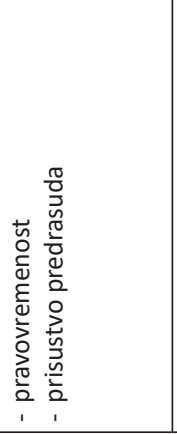 & 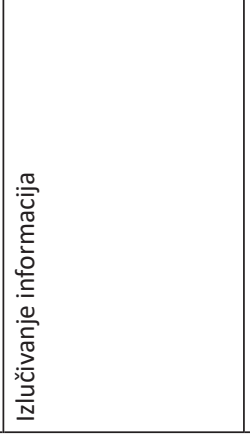 & 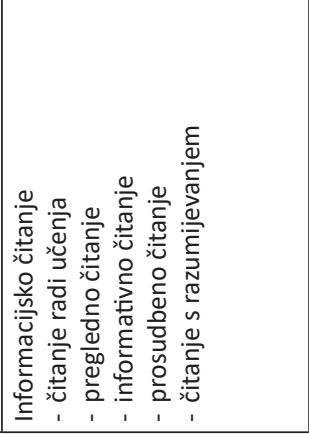 & 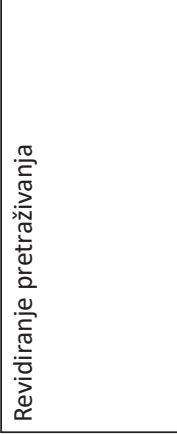 \\
\hline
\end{tabular}




\begin{tabular}{|c|c|c|c|c|}
\hline 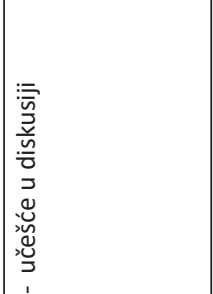 & 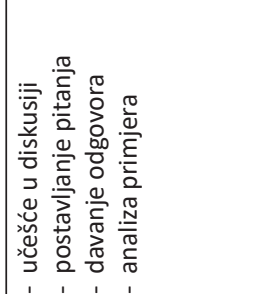 & 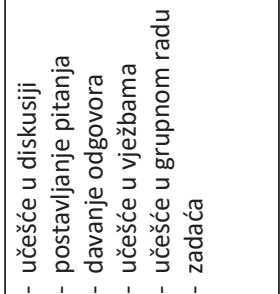 & 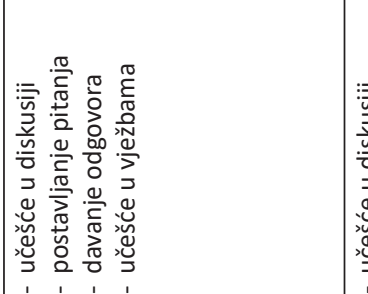 & 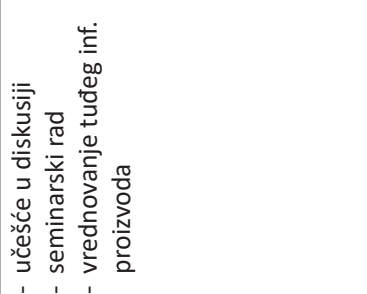 \\
\hline 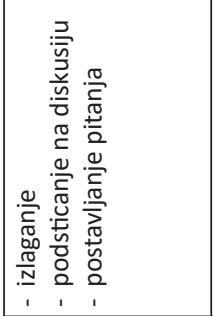 & 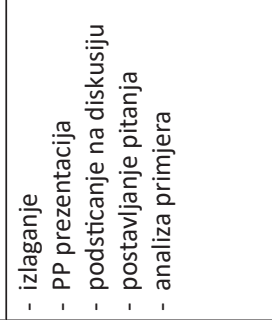 & 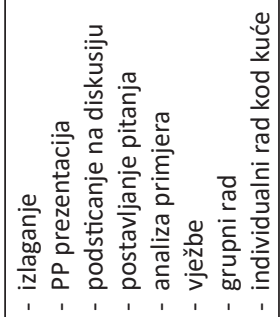 & 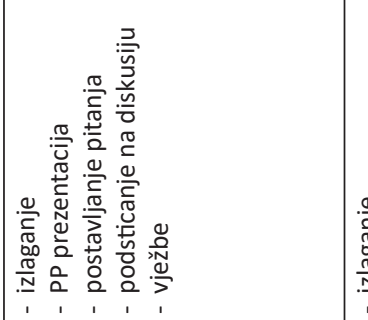 & 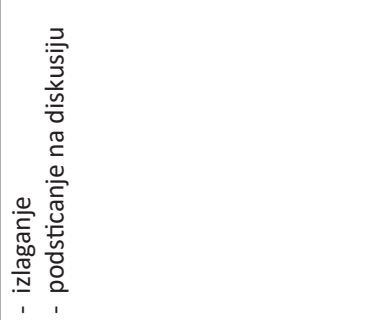 \\
\hline 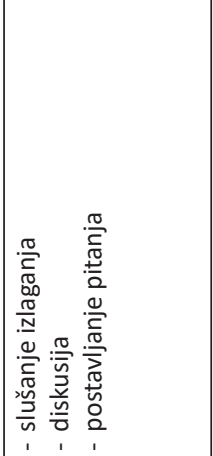 & 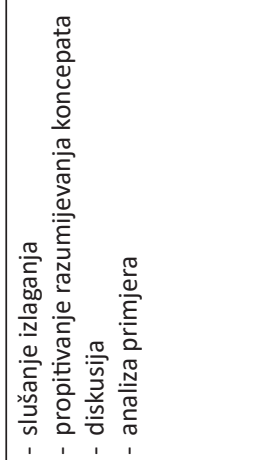 & 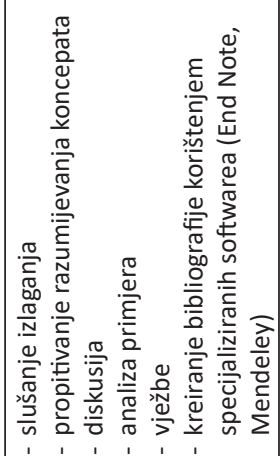 & 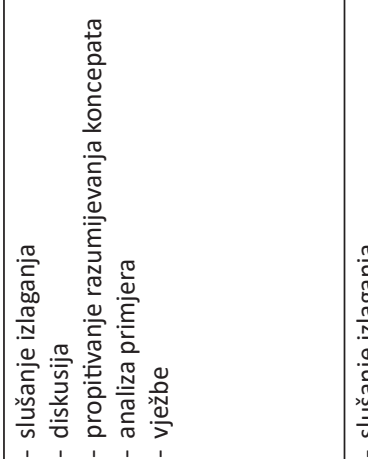 & 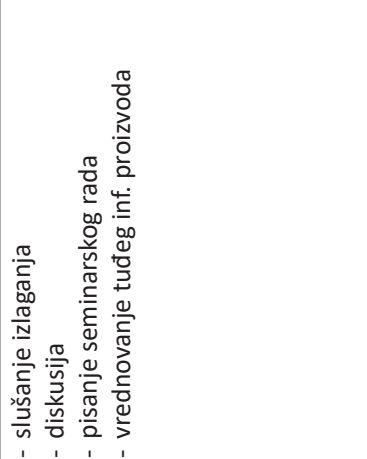 \\
\hline 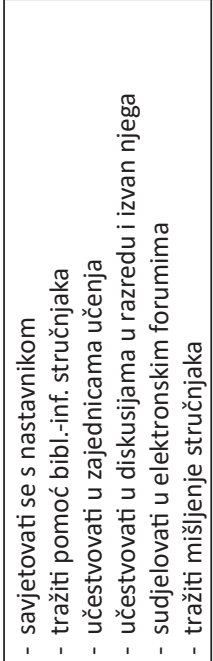 & 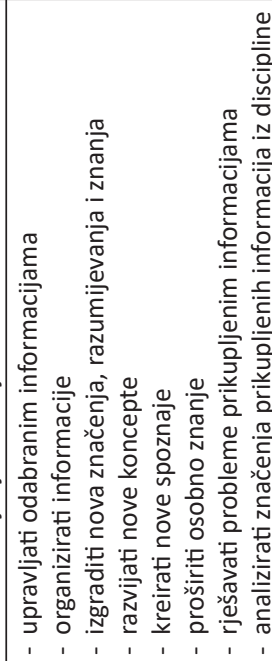 & 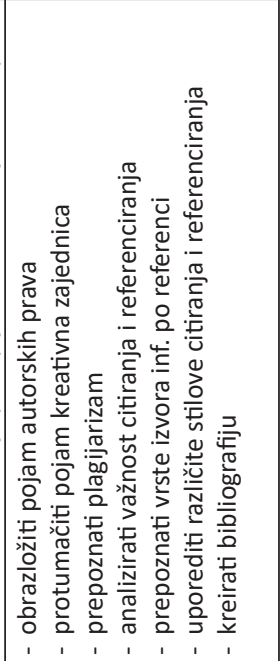 & 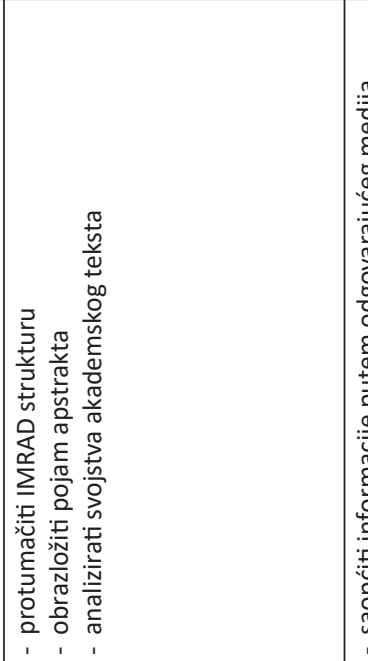 & 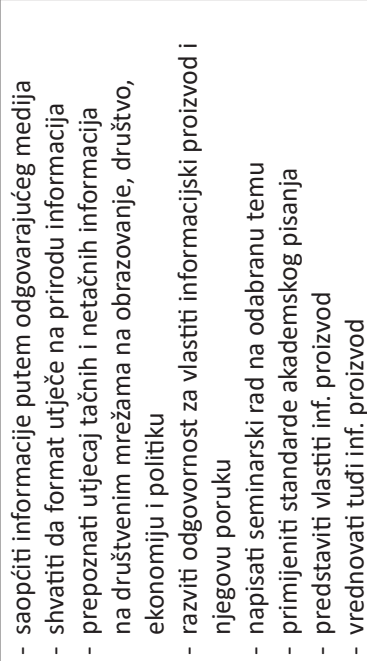 \\
\hline 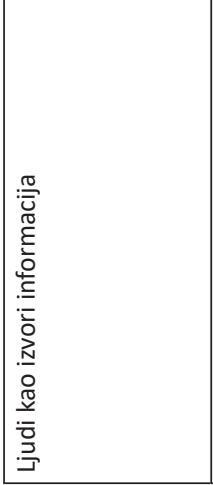 & 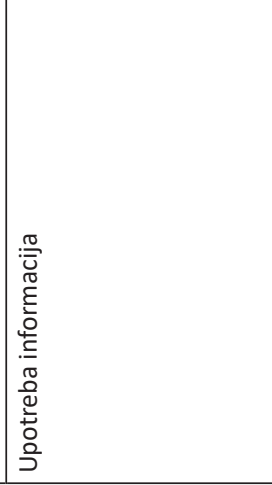 & 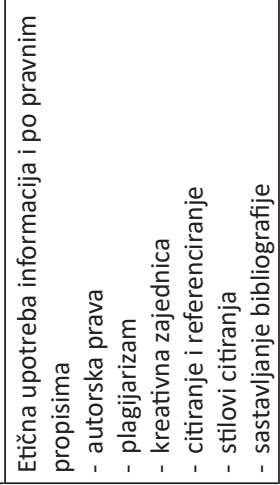 & 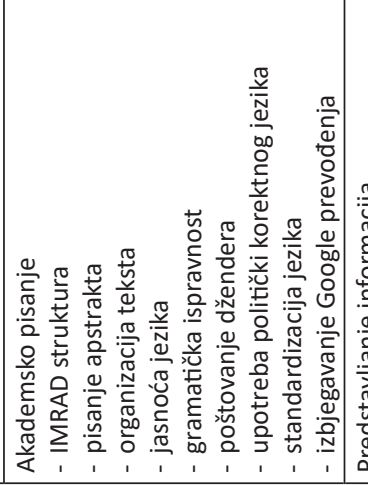 & 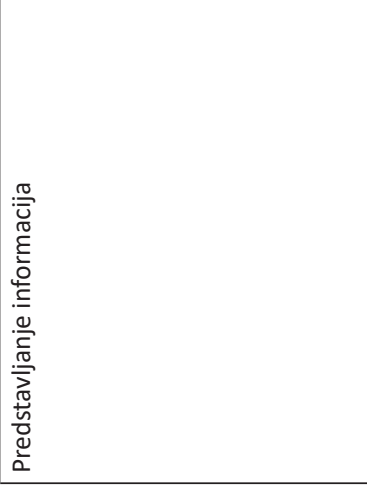 \\
\hline
\end{tabular}




\section{Zaključak}

Predstavljeni okvirni kurikulum informacijske pismenosti povezuje sve važne elemente informacijske pismenosti u odnosu na ključnu ulogu informacijske pismenosti u obrazovanju, okruženju radnog mjesta i sudjelovanju u civilnom društvu u smislu svojevrsnog kružnog toka u stjecanju metakompetencija za izgradnju znanja kroz stvaranje vlastitog informacijskog proizvoda koje započinje pristupom mnoštvu široko distribuiranih informacijskih izvora i završava kao dio toga mnoštva.

\section{Literatura}

- Kennedy, Declan. 2006. Writing and using learning outcomes: a practical guide. Cork: University College Cork. https://cora.ucc.ie/bitstream/ handle/10468/1613/A\%20Learning\%20Outcomes\%20Book\%20D\%20Kennedy.pdf? sequence. Datum pristupa: 26. 8. 2019.

- Kovačević, Dinka, i Jasmina Lovrinčević. 2014. Mjerila kvalitete rada u hrvatskom školskom knjižničarstvu. Osijek: Odjel za kulturologiju u sastavu Sveučilišta Josipa Jurja Strossmayera.

- Lončar-Vicković, Sanja, i Zlata Dolaček-Alduk. 2010. Ishodi učenja: priručnik za sveučilišne nastavnike. Osijek: Sveučilište Josipa Jurja Strossmayera.

- Machala, Dijana. (2009). "Ishodi učenja u nacionalnom programu trajne izobrazbe knjižničara” U Cjeloživotno učenje knjižničara: ishodi učenja i fleksibilnost, uredile Aleksandra Horvat i Dijana Machala, 41-55. Zagreb: Nacionalna i sveučilišna knjižnica.

- Mackey, Thomas P., i Jacobson, Trudi E. 2011. "Reframing information literacy as a metaliteracy" College \& Research Libraries 76(1): 62-78. https:// crl.acrl.org/index.php/crl/article/view/16132. Datum pristupa: 27. 8. 2019.

- Pastuović, Nikola. 1999. Edukologija: integrativna znanost o sustavu cjeloživotnog obrazovanja i odgoja. Zagreb: Znamen.

- $\quad$ Pastuović, Nikola. 2012. Obrazovanje i razvoj: kako obrazovanje razvija ljude i mijenja društvo, a kako društvo djeluje na obrazovanje. Zagreb: Institut za društvena istraživanja.

- Previšić, Vlatko. 2007. "Pedagogija i metodologija kurikuluma" U Kurikulum: teorije - metodologija sadržaj - struktura, uredio Vlatko Previšić, 15-37. Zagreb: Zavod za pedagogiju Filozofskog fakulteta Sveučilišta u Zagrebu - Školska knjiga.
Okvirni kurikulum je zamišljen kao otvoreni, fleksibilni kurikulum uz mogućnost individualizacije, razrade i dopunjavanja prema potrebama konkretne situacije ovisno o ciklusu studija i znanstvenoj disciplini te načinima implementacije u okviru fakultetskog kurikuluma. Osnova je za detaljno planiranje nastavnih cjelina i metoda njihovog izvođenja, a inoviranje i dopunjavanje je poželjno u svim njegovim segmentima kako bi bio primjenjiv u različitim obrazovnim okruženjima.

- $\quad$ Rašidović, Beba Ešrefa. 2016. "Model prožimanja komponenti u curriculumu Fakulteta za kriminalisti$\mathrm{ku}$, kriminologiju i sigurnosne studije Univerziteta u Sarajevu" Zbornik radova Odsjeka za pedagogiju 1(1): 249-257. http://www.ff-eizdavastvo.ba/Books/ SerialPubl/ped/ZR_odsjeka_za_pedagogiju.pdf.

- Rašidović, Beba Ešrefa. 2011. "Informacijska pismenost i visokoškolske biblioteke - edukacija korisnika. Model Univerziteta u Sarajevu" Magistarski rad, Univerzitet u Sarajevu.

- Špiranec, Sonja, i Kos, Denis. 2013. "Information literacy practices and student protests: mapping community information landscapes" Information Research 18(3), paper C39: 1-12. http://informationr. net/ir/18-3/colis/paperC39.html\#.XWTswd4zbhk. Datum pristupa: 27. 8. 2019.

- Thompson, Gary B., i Lathey, Jonathan W. 2013. "An integrated model of information literacy based upon domain learning" Information Research 18(3), Paper C02: 1-14. http:// http://www.informationr. net/ir/18-3/colis/paperC02.html\#.XWTpzN4zbhk. Datum pristupa: 27. 8. 2019.

- Uvod u projekt Usklađivanje obrazovnih struktura u Europi. Sveučilišni doprinos Bolonjskom procesu. Tuning educational structures in Europe. 2007. http:/www.unideusto.org/tuningeu/images/stories/ documents/General_brochure_Croatian_version FINAL.pdf. Datum pristupa: 27. 8. 2019. 


\section{INFORMATION LITERACY COURSE CURRICULUM}

\section{Abstract}

The context of the information society and the knowledge society is a challenge for new education policies, which are adapted to the needs of the labour market. The labour market requires constant improvement and acquisition of new knowledge and skills, which implies a continuous learning process. Meta-competencies of information literacy contribute to the development of creative competences for lifelong learning by educating all participants in educational processes for better, more efficient, purposeful and better use, for building knowledge, relevant information and sources of information, regardless of whether information sources and information are contained in analogue, digital or virtual origin. Such importance of information literacy produces the need to incorporate these meta-competencies, as fundamental ones, into all teaching and science processes. With the further development of information literacy, in the context of changes in society, reforms within higher education, a changed educational paradigm, and ways of learning, it is necessary to define an information literacy curriculum in accordance with the principles of active learning. The aim of the paper is to present a framework curriculum for the information literacy course.

Keywords: information literacy, information literacy meta-competencies, independent course, information literacy course curriculum 